\title{
James Anta: Missionary, Martyr and unsung Hero of the Wesleyan Methodist Church in Zimbabwe
}

\author{
Martin Mujinga \\ https://orcid.org/0000-0001-8098-2515 \\ University of South Africa \\ martinmujinga@gmail.com
}

\section{Abstract}

The history of Wesleyan Methodism in Zimbabwe speaks loudly about the role played by the first missionaries. Most scholars credit these missionaries for the sacrifices they made. However, the expansion of the mission was largely the work of teacher-evangelists from South Africa. Among them were Modumedi Moleli and James Anta. Moleli and Anta were martyred in Mashonaland during the Shona uprising of 1896-1897. Although the two evangelists came to Zimbabwe during the same period and were killed in the same epoch through the same type of brutality, Moleli received scholarly attention and church recognition. On the one hand, Brandon Graaf dedicated a book to Moleli and on the other hand, the church named a school after him. Moleli died in Mashonaland East and was buried at Nenguwo (now Waddilove) Training Institute, whereas the school in his honour is located in Mashonaland West, where James Anta was killed. In contrast, there is neither a building nor scholarly work dedicated to Anta. This paper argues that, although Anta's name is mentioned in the Wesleyan Methodist literature, there is deliberately no attempt to honour his martyrdom as central in the growth of Methodism in Zimbabwe. By using qualitative research methodology, the paper challenges the Wesleyan Methodist Church to reconstruct its ecclesiastical history to honour Anta, who came to Zimbabwe as a missionary in his own right. The paper concludes by arguing that the historiography of Methodism in Zimbabwe is incomplete without acknowledging Anta as a missionary, evangelist and martyr; and yet he remains an unsung hero.

Keywords: James Anta; missionary; martyr; unsung hero; Wesleyan Methodist

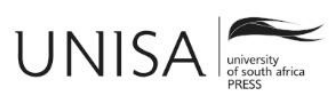

Studia Historiae Ecclesiasticae https://unisapressjournals.co.za/index.php/SHE/index Volume 47 | Number 3 | 2021 |\#9520| 15 pages 


\section{Mujinga}

\section{Introduction}

The early history of Wesleyan ${ }^{1}$ Methodism in Zimbabwe has been written over time, and scholars such as Banana (1991), Gondongwe (2011), Madhiba (2000), Mawire (2015), Mujinga (2017), Thorpe (1951), and Zvobgo (1991) have done well in narrating this history. The key people in these narratives had been the missionaries and the teacher-evangelists from the Sotho and Xhosa tribes of South Africa. These scholars clearly articulated how South African teacher-evangelists from the Transvaal and Cape Colony played a pivotal role in the propagation of the gospel in the then Mashonaland (now Zimbabwe). Of these agents, two are outstanding and these are Modumedi Moleli and James Anta. Moleli and Anta were martyred during the Shona uprising of 18961897. Modumedi Moleli was killed in Mashonaland East, while James Anta was assassinated in Mashonaland West. There is a distance of over $200 \mathrm{~km}$ between the places of their execution. Moleli was killed at the Nengubo Mission on Sunday 21 June 1896, and James Anta was killed in the Banket/Zvimba area of Hartleyton on 18 July 1896. The two teacher-evangelists were accused of being sell-outs to the white colonisers (Gondongwe 2011, 79).

It is evident that Moleli and Anta came for the same mission, during the same period, working with the same missionaries, operating in Mashonaland, and they both died during the same upraising; yet Anta appears to have been forgotten in the history of Wesleyan tradition. Of interest to note is that, when the Methodist Church in Zimbabwe (MCZ) developed Marshal Hartley in Mashonaland West into a boarding school, the institution was named after Moleli, who was killed in Mashonaland East. Up to the time of writing this paper, MCZ had not done anything to honour James Anta. Being among the first teacher-evangelists who propelled the gospel in Mashonaland, Anta did not receive any scholarly attention. There are four sources of information that give Anta's narratives; however, most of them are not scholarly literature to declare Anta as a centre of the Wesleyan Methodist historiography. By using qualitative research methodology, this paper will use these four sources to argue that the history of the Wesleyan Methodist Church does not do justice by forgetting the life and ministry of Anta in their historiography. The paper challenges the Wesleyan Methodist Church to revisit the history of Anta because his blood, together with that of Moleli, was the seed of the gospel in Zimbabwe.

\section{A Critique of the Literature on James Anta}

As argued earlier, four sources of literature are critical in the reconstruction of the life and history of James Anta. The first source of information is an online narrative by Ezika Matshobana, who concluded the account of Anta by apologetically saying: "If you feel this is not an accurate profile and you have a more accurate one, or you have a

1 There are two strands of Methodism in Zimbabwe. The one that came through America is the United Methodist Church, while the one that came through Britain is known as the Wesleyan Methodist Church. In this paper, Wesleyan Methodist will also be called Methodist Church in Zimbabwe, acronymic MCZ. 


\section{Mujinga}

clarification, you can submit your version of the profile here" (Matshobana n.d.). Although Matshobana can be credited for attempting to reconstruct the forgotten history of Anta, two things outweigh his account. First is his apologetic statement, which proves that he did not have enough information to credit James Anta. Second, Matshobana's narrative was not interested in the role played by Anta in Wesleyan Methodism. The absence of such critical information creates a vacuum in the life of a teacher-evangelist, martyr and missionary, whose martyrdom propelled the growth of Methodism in Zimbabwe.

The second source is the uncoordinated scholarly literature by MCZ scholars, such as Banana (1991), Gondongwe (201), Madhiba (2000), Mawire (2015), Mujinga (2017), Thorpe (1951), and Zvobgo (1991). Although these scholars wrote intensively on the history of the Wesleyan Methodist Church in Zimbabwe, the name of James Anta appears ordinarily in their writings. There was no attempt by MCZ scholars and historians to dedicate any literature to Anta. Instead of anchoring the history of the Wesleyan Methodist Church on two martyrs, namely Anta and Moleli, who were both killed in Mashonaland during the same year, Anta appears to be forgotten history. Rev. Brandon Graaf, one of the Wesleyan missionaries to Zimbabwe, wrote a book titled Modumedi Moleli: A Teacher, Evangelists and Martyr to Mashonaland between 18921896 (Graaf 1988). On the cover page of the book where he was giving a summary, Graaf argues: “... the story of Moleli has unfortunately escaped most Zimbabwean writers." Graaf further argues that Moleli's life and work are commemorated annually at Waddilove Training Institute in Marondera on 24 June, but little is known about him, even within the institution where the author of this biography is indeed filling the gap (Graaf 1988). Graaf's work is commended because he unveils the forgotten history of Moleli as a missionary; yet neither he nor any other missionary or Methodist scholars paid attention to the details of the impact of the martyrdom of James Anta to the Wesleyan historiography.

It cannot be denied that Anta's ministry to Mashonaland was bigger than his age, given that he was a young and unmarried Xhosa who sacrificed his life and future as a teacherevangelist in Mashonaland (Samkange n.d.), and yet he remains an unsung hero. What is even more fascinating about his pigeonholed history, is that the Wesleyan Methodist Church dedicated a boarding school in the Zvimba area in Mashonaland West Province (where Anta was killed) to Moleli, who was killed in Mashonaland East. This scenario has led Moleli to be celebrated by both Mashonaland East and West, and yet Anta's narrative is uncelebrated.

The third source of information is a report on the visit to Banket (at the death spot of Anta) by Rev. Naison Makwehe, Prof. Stanlake Samkange and Rev. Charles Manyoba on 23 June 1986. The visit was done 100 years after the death of Anta. Makwehe, Samkange, and Manyoba (1986) recorded that Anta was killed at a place called Watson Farm, six kilometres south of Banket close to the Harare railway. The trio also reported that "the site of Anta's death place is among the rocks and boulders, the largest of which 


\section{Mujinga}

are similar to those in the area of Cecil John Rhodes' grave and has a pronounced dignity of its own" (Makwehe et al. 1986). In their summary report, Makwehe et al. (1986) mention that there were attempts to honour Anta by the Methodist Church in 1971 and a church service was conducted on the site to mark the historical spot (Makwehe et al. 1986). The service was attended by the then president (now Presiding Bishop ${ }^{2}$ ) Rev. Andrew Ndhlela, Rev. Matthew Rusike ${ }^{3}$ and Chief Patrick Zvimba (Makwehe et al. 1986). After the visit, two recommendations were made to the 1986 Conference to consider. The first one read "that a Memorial should be built on the site and a cross be put on the rock above the Memorial"; the second, that "a Memorial school or church be built at the suitable place in the Makwiro Circuit in honour of Anta" (Makwehe et al. 1986). When the Conference received the report, first, they appointed Prof. S.J.T Samkange to produce a written history of James Anta (MCZ 1986, R10). Second, the Conference also agreed that Rev. Manyoba, Prof. Samkange and Rev. Makwehe give further considerations to a suitable memorial for Evangelist James Anta, and to produce material for teaching for the Methodist community (MCZ 1986, R10). Unfortunately, MCZ did nothing to honour Anta after the 1986 Conference.

The fourth source that benefited this research is the undated narrative by Samkange in response to the task he was given by the MCZ Conference of 1986. This narrative was drawn from the MCZ archives in Harare. In this writing, Samkange (n.d.) argued: "James Anta was one of whom, in the spirit of Christ, had come to serve and not to be served" (Samkange n.d.). Samkange acknowledged that although Anta is mentioned in Methodist literature, nothing further has been recorded about him since 1896. At times when his name was mentioned, it was but in passing rather than to do anything about him (Samkange n.d.). Samkange bemoaned that, although Anta's death was referred to at the Methodist Centenary Celebrations, ${ }^{4}$ he merited merely one or two references, largely because so little is known of him and no attempt has been made to unveil the circumstances surrounding his death. There has been no appreciation of the events which occurred around him, and which made his death inevitable (Samkange n.d.). Samkange agrees with Matshobana that there was very little personal information known of Anta, and yet he had rare qualities. Although Samkange's report is critical in giving credence to Anta, his work remains archival literature, thereby suppressing the

2 When the Wesleyan Methodist Church got autonomy from the British Methodist Church in 1977, the title of the head of the church was president. In 1980, when one of the Wesleyan Methodist clerics, Prof. Canaan Banana, became the state president (of Zimbabwe), there was a challenge in the ecclesiastical meetings as to who was being addressed, the church or state president. The title of the church leader was changed to bishop. In 2004, the name was further changed to the presiding bishop and the title bishop was given to the district/diocesan leaders.

3 Rev. Matthew Rusike is the founder of the first African Children's Home, now called Matthew Rusike Children's Home. He was also the first minister to be stationed in the Zvimba area, 53 years after the death of James Anta (Mujinga 2020, 7).

4 The Wesleyan Methodist Church in Zimbabwe celebrated 100 years of the planting of Methodism to Zimbabwe from 1891-1991. 


\section{Mujinga}

identity of Anta; in which case this paper endeavours to uncover these hidden identities and make Anta "live" in the life and mission of Wesleyan Methodism in Zimbabwe.

\section{Synopsis of the Transplantation and Challenges of Methodism to Mashonaland}

MCZ scholars generally agree that Methodism was established in 1891 with the arrival of Owen Watkins and Isaac Shimmin from South Africa. These scholars also agree that the propagation of the gospel in the then Mashonaland was possible because of the teacher-evangelists from the Transvaal and Cape Colony in South Africa. According to the narratives of Clarence Thorpe, who was the first missionary to write down the history of Methodism in Zimbabwe, the coming of Wesleyan Methodism in Zimbabwe was a political expansion of Cecil John Rhodes (Thorpe 1951). Rhodes's offer to bring Wesleyan Methodism to Mashonaland had to be referred to London, but did not reach the Home Committee until after the arrival of the Pioneer Column at Fort Salisbury (now Harare) in 1890 (Thorpe 1951, 39). At first, the Methodist Mission Committee in England had reservations to allow Watkins to cross the Limpopo to plant Methodism in Mashonaland because of two reasons. First, the number of mission centres that were being opened in the Transvaal, was increasing. Second, the missionary income was declining. Watkins was persuaded by Rhodes who offered $£ 100$ a year towards establishing a Wesleyan minister in Mashonaland (Mawire 2015, 44; Thorpe 1951, 39). This decision was accepted by the British Conference and Watkins was allowed to cross to Mashonaland to take a trial mission. ${ }^{5}$

The appointment of Watkins to be a trendsetter in planting Methodism in Mashonaland was the best choice because of a number of factors. First, Watkins had the leadership experience needed for the missionary enterprise because he was the chairman and general superintendent of the Transvaal district under the British Conference. Second, Watkins had an appreciation of the impact of the local people in establishing the church among the locals because the Transvaal Methodist mission work was started by South African lay people, some of whom are key in the history of the Methodist Church of Southern Africa, like David Magatha and David Msimang (Kumalo 2009) who together with Watkins planted Methodism in Swaziland (Hewson 1951, 47). With Msimang, Watkins also undertook the arduous journey into Zululand. However, while still pondering this mission among the Zulu people, he received a call from Robert Mashaba to come to Portuguese East Africa (now Mozambique) to plant the mission there (Hewson 1951). Watkins also worked with Samuel Mathabathe in 1883. The Wesleyan Methodist Missionary Society purchased a farm at Good Hope to accommodate Mathabathe's converts and the Good Hope Mission was born. Watkins visited Mathabathe, and described him as "having the courage of the apostle Paul and the tenderness of the apostle John" (Hewson 1951, 51). Mathabathe worked as an evangelist

5 A trial mission was a district established by the Wesleyan Methodist Mission Department in Britain to operate, while the Conference was assessing the mission to ascertain whether it would be possible to occupy a certain geographical area (Mujinga 2017, 116). 


\section{Mujinga}

for nine years, "unknown, unpaid and unvisited" (Millard 1999). In 1885, at the age of 45 , Mathabathe was presented as a prospective candidate for the ministry. He found that he could not master the study needed for ordination so he remained an evangelist.

From the engagements of Watkins and the local evangelists, it is evident that he was a missionary who appreciated the services of the native agents. It is not surprising that when he was crossing the Limpopo to Mashonaland, he took with him teacherevangelists because he had seen their impact in propagating the gospel (Mujinga 2017, 113). In his appreciation of the local agents, Watkins (in Hewson 1951) wrote:

... it is sad that sacrifice to heroes must be reserved until after sunset. I don't believe this. One principle of the Mission we ever bear, in mind, that we must use the minimum of the Whiteman and the maximum of the Native men. Already, we have a band of Native helpers ... who when the literary men of our Mission arise, shall be glorified in a book. Hitherto, God himself has sent out the men, and they owe little to human agency, but all to the divine ... but it will be evident to you that we not only need evangelists, but teachers. Teacher-evangelists supply that need to the best ability-because soon after hearing the gospel, people would want a school. (Hewson 1951, 51)

The teacher-evangelists were important in Watkins's trial mission, if the work was to be accomplished. As young men in ministry, the teacher-evangelists were going to labour amongst the people who had just "emerged from heathenism" [sic] (Hewson 1951, 51). Watkins also brought with him the Rev. Isaac Shimmin, a "young man" in his late forties. The two missionaries were accompanied by John Peters, who was Watkins's African driver of his wagon, and John Walters, a Cape Coloured who was leading the ox-drawn wagon (Thorpe 1951, 42). They left Kilnerton, Pretoria on 2 June 1891 and they arrived at Limpopo on 14 July 1891. Watkins wrote: "the crossing of the Limpopo was not easy because the river was so deep that in one place only horns of the united strength of the forty four patient oxen used to cross the vicious river were visible" (Thorpe 1951, 41). The pioneer column and the missionary journey arrived together on 29 September 1891. Upon their arrival, mission work started. Shimmin's first service was held in a shop. The reading desk was a shop counter, a few soap boxes were the pews and the congregation of four men crowded in the service (Thorpe 1951, 43).

Watkins did not stay long in Mashonaland; he left the mission with Shimmin. Mission stations were established, including areas like Nengubo and Kwenda in 1892. Watkins and Shimmin brought with them some of the teacher-evangelists, like Michael Bowen. On 2 December 1891, Shimmin, together with evangelist Michael Bowen, left for Nemakonde ${ }^{6}$ with the hope of finding a place for a farm. On 15 December 1891 they marked out the new mission farm, which they named Hartleyton in honour of Rev. Marshal Hartley, who was the secretary of the Wesleyan Methodist Missionary Society in England (Gondongwe 2011, 49; Mujinga 2020, 7; Zvobgo 1991, 56). In 1894, a new mission station was begun at Marshal Hartley farm (Thorpe 1951, 101). After this

6 In this article, the names Nemakonde, Lomagundi, Zvimba or Hartleyton refer to one area. 


\section{Mujinga}

reconnaissance trip, Bowen became fluent in Shona. He made many contacts with the people and left them with the sense that they were quite ready to hear what the Christians had to say and to benefit from sustained teaching. Shimmin wrote to Marshall Hartley in London, saying: "We could find work for at least dozen evangelists" (Samkange n.d.). At this time, the Methodist extension work in Mashonaland was being directed and monitored through the existing work of the Wesleyan Methodist Missionary Society in the Transvaal, where Rev. George Weavind was the chairman of the Transvaal district. When missionary work continued to grow in Mashonaland, Weavind was tasked to find volunteers to cross the Limpopo to beef up the workforce in Mashonaland.

Weavind sent Rev. George H. Eva, a fluent Zulu linguist, and the other African evangelists and teachers and they arrived from the Transvaal and Cape Colony in August 1892 (Gondongwe 2011, 216). Among these teacher-evangelists were three Sotho tribesmen, namely Josiah Ramushu, Mutsualo and Modumedi Moleli. The other seven evangelists were Xhosa men, namely Samuel Tutani, Wellington Belesi, Mutyuali, Mulau Fokasi, James Anta and Shuku (Thorpe 1951, 54). Of these evangelists, five returned home in due course. Two of the remaining five, namely James Anta and Modumedi Moleli, died during the Shona uprising also known as the First Chimurenga. ${ }^{7}$ The remaining three made Mashonaland their home. Josiah Ramushu was to be the first black minister to be ordained in the Wesleyan Methodist Church. Samuel Tutani and Wellington Belisi later also became Methodist ministers (Gondongwe 2011). Josiah Ramushu and his three sons, Oswald Ramushu (1943 to 1990), Willie J Ramushu (1937 to 1979) and David Ramushu were Methodists Ministers (Thorpe 1951, 58), while some of the lay members of the Ramushu family became church leaders. For example, Aaron Ramushu was the connexional lay leader between 1993 and 1995 (Mujinga 2017, 164). Herbert Ramushu also became the connexional treasurer while his wife, Mantinti Ramushu, joined the Methodist ministry as a local (part)-time minister from 1995-2020.

Isaac Shimmin believed that the evangelisation of Africa could best be done by Africans witnessing to fellow Africans (Banana 1991, 8). Explaining the role of the teacherevangelist, Shimmin wrote:

The Africans are to be served by Africans themselves is a favourite theory of most Christian workers out there and in this new mission we are proceeding on these lines. Under the most careful and constant supervision of the minister, the native evangelist can become the most effective missionary and especially in a country like Mashonaland. (Banana 1991, 9)

It is this conviction and the capability of African evangelists that made them sacrifice their lives for the gospel. There were a number of challenges that the African agents faced in their effort to propagate the gospel. First, they were not familiar with the religious and geographical terrain of their new territory of operation, hence the need for

Chimurenga is a Shona word which means revolutionary struggle. 


\section{Mujinga}

people with that kind of indigenous knowledge. Second, the South African indigenous agency did not speak the language of the majority of the Zimbabwean people and this made communication difficult, especially given the fact that the White missionaries desperately needed translators. Third, although these South African agents were Africans, the Zimbabwean people regarded them as foreigners and therefore always suspected them of being in complicity with the Whites (Gondongwe 2011, 337).

In 1896, the Mashona ${ }^{8}$ people followed the example of the Matabele and rose in revolt. Over a hundred Europeans were killed within a week in Mashonaland. One of them was James White. White was in the vegetable garden when his place was attacked by the Mashonas and they killed his companion, Captain Bremner, with a single blow from the axe (Thorpe 1951, 66). White managed to drive the revolters away with a gun. Late in the afternoon, Moleli came to take White to the mission station and the rebels attacked them and killed both (White and Moleli). Moleli's wife tried to dissuade her husband but he said: "I am a Christian teacher and I must do what is right at all costs" (Thorpe 1951, 66).

Another example of an evangelist who suffered hostility was that of an Anglican teacher, Bernard Mizeki, who was murdered in 1896 in Marondera under similar circumstances. The death of Mizeki was the result of protracted hatred between himself and an African religious functionary. For a long time, Mizeki had condemned the work of the traditional healer who resided near his home. On the other hand, the traditional healer was an avid hater of Christianity. He hated Mizeki and the Whites. Mizeki was described as the evil genius of the district. When the news spread that the Mashona had engaged in a rebellion, the traditional healer saw this as the chance to eliminate Mizeki and he utilised it (Gondongwe 2011, 80). Although the gospel prospered, it cannot be denied that the blood of the martyrs was a seed for the gospel.

\section{Life and Ministry of James Anta in Mashonaland}

The first groups of indigenous ministers to come to Mashonaland were recruited from the teachers who had accompanied the pioneer Methodist missionaries on their journey from South Africa. This group was not much concerned about remuneration, for their mission was to participate in the conversion of their fellow Africans. What made them volunteer to cross the Limpopo River into Mashonaland, was their religious zeal. They were soldiers of Christ, determined to leave everything for the sake of the gospel (Gondongwe 2011, 119). One of them was James Anta.

The identity of James Anta is controversial. On the one hand, Samkange (n.d.) mentions that Anta was a young and unmarried Zulu, with a reputation as a hunter from the Transvaal. On the other, Matshobana (n.d.) does not agree with the above assertion of identifying Anta with the Zulu tribe, but with the Zulu language. Matshobana (n.d.) mentions that Anta was a Xhosa man from the Eastern Cape in South Africa and was a

Refers to the Shona-speaking people, while Matabele refers to the Ndebele-speaking people. 


\title{
Mujinga
}

son of a chief who was under the influence of the Wesleyan Missionaries that were working in the area. Anta converted and was baptised James. From there on, he channelled all his efforts to spread the word of God. Matshobana further argues: "... the fact that Anta learnt to read and write fluently in Zulu, a common practice in those days, many people have mistakenly assumed he was Zulu." This identity of Anta as Xhosa was also supported by Thorpe (1951) and Zvobgo (1991) and the writer is also adding weight to the Xhosa identity of Anta because there is no evidence from the Methodist historians that the Zulu people came to Mashonaland.

In about October 1891, Cecil John Rhodes granted Rev. Owen Watkins three farms to build Wesleyan Methodist missions in Mashonaland. In order to assist with the running of these embryo missions, the Transvaal district made arrangements for some voluntary African agents who arrived on the last Sunday of May 1892 and were initially stationed at Epworth, Rhodesia (now Zimbabwe). Whereas Moleli, Tutani and Belesi went off to the south east area, Michael Bowen, Isaac Shimmin, James Anta and the two unmanned evangelists prepared to travel in a north-westerly direction to Hartleyton and Lomagundi to complete the work they had set out to do the previous October. Josiah Ramushu and George Eva remained in Harare. In writing about their journey to Lomagundi, Isaac Shimmin had this to report:

\begin{abstract}
We decided to make our first journey in the direction of Hartleyton and Lomagundi's, and by 1st September we were ready to start. There were eight of us altogether, four of the new teachers, besides Michael, the driver, the leader and myself. The small wagon was heavily laden. Our six oxen were in good condition, and we set off with bright hopes of a prosperous journey. Passing the famous Mount Hampden, we trekked steadily on and got to our old friend Chief Zvimba's within a week. ... You remember my visit here last December and the pegging out our mission farm at Hartleyton. The Chief was greatly delighted to see us again; he had come to the conclusion that we had altogether forgotten our promise to send him a teacher. (Samkange n.d.)
\end{abstract}

Shimmin was referring to James Anta as the new teacher. Anta worked entirely in isolation amongst a people whose language and culture were foreign to him (Matshobana n.d.). True to his missionary calling, Anta forged along and endured the hardships that came along with his divine calling. He permanently established himself in Zvimba's kraal, where he built a rough pole and mud school/church. One of his students recalled "... he used small Xhosa/Fingo spelling books for teaching spelling. He taught counting one to ten and beyond in English. The children used slates. Anta read from the Zulu Bible, doing his best to translate into Shona. There were no games" (Matshobana n.d.). As a result of his work, some families began to regard their homes as mission ground. This made it possible for continuous teaching to take place and for the work of building Christian communities to begin; and the work progressed.

In 1893 there were three evangelists working in the area. In and around Hartleyton they visited three places, where together there were about 200 children in school (Samkange n.d.). Anta had a wagon and used to go to Harare to get his rations. He had a gun and 


\section{Mujinga}

he liked hunting. When he had shot an animal, he would call the people to share it. The people flocked to the church because of how Anta treated them. Since he was a young man, the chief wanted to find a wife for him (Samkange n.d.). Despite these apparent successes, there was growing resistance to the missionary work from White settlers and the traditionalist. On the one hand, the White settlers saw the missionary work as interference; they just wanted the Shona people to work in their mines. On the other hand, the traditionalists, especially the elders, saw the new doctrine of "equality for all under the eyes of God" as being a threat to their status in society (Matshobana n.d.). These scenarios created a vacuum between the missionaries, the settlers, the indigenous and the rebels, leading to the persecution of the teacher-evangelists.

\section{The Martyrdom of James Anta}

James Anta was a martyr, but not by choice. The events that conspired to the death of Anta left him with no route to escape. In 1894, during a patrol to enforce the payment of new hut tax (an issue that made no sense to the locals), a man called Trooper Cooper was killed. This left the Lomagundi area in fear. After the reports of the Matabele rising had reached the Mashonaland, the Mashona started to plot an uprising against the White settlers, encouraged by the spirit mediums of Kaguvi and Nehanda. This occurred at Lomagundi's kraal, some distance west of Hartleyton (Samkange n.d.). A police patrol was sent from Salisbury (now Harare) to investigate the death of Cooper. The patrol arrived in Hartleyton on Sunday, during a James Anta led church service, being attended by almost all of the natives. George Eva wrote on 13 October 1897, saying:

I was at my station at Zvimba in the Lomagundi District on the last Sunday of September. I had arrived there from the Civil Commissioner's camp on the Saturday. We succeeded after much persuasion and a good deal of trouble to get most of the people in the district to come together on our station. Those who had arrived numbered about 500 or 600 souls and some chiefs or indunas. We had gathered them together for service. All had come to the service with the exception of one woman who had a sick child. I was just finishing my address when James the teacher saw a policeman following the woman who had a sick child and who was walking as fast as she could for our meeting place. I turned around and saw James going to the policeman. I immediately broke up my address and went to get the native constable to keep watch. I found out from the constable that there were a number of policemen coming up with vile. I told the teacher we might close the service and gather the children together to sing the closing hymn. They were in the midst of this, when sub-inspector Hopper arrived with Mr. Arthur Eyre, Mr. Kenny and three policemen. Mr. Hopper got off his horse and called Mr. Kenny to interpret for him ... (Samkange n.d.)

Hopper called together all the chiefs and told them to follow him because the government wanted them to assist the police who were looking for Mzimbagupa, the murderer of Trooper Cooper of the Lomagundi district who had come to collect cattle. Next, the police announced that the chiefs were now prisoners and instructed them to walk in the direction of the village (Gondongwe 2011). Within no time, three chiefs 


\section{Mujinga}

were killed. Eva gave a verbatim narrative of what happened when the chiefs were killed.

We rushed down to where the police were encamped to find only three of the seven chiefs remaining. I saw sub-inspector Hopper and spoke to him and he said to me, your Indunas have run away and he was sorry for what had happened but there was no other alternative. Whilst we were talking, I heard a shot fired close to where we were standing and it was followed by a cry in Mashona, Maiwe, Ndabaiwa, "Oh I am shot" and a policeman returned saying "I have done for him." Three of the four who ran away were shot, the fourth could not be found. I saw him in the evening after the police had gone. ... The chiefs were absolutely innocent of Cooper's death, to this I am prepared to take an oath. For when it occurred, I was amongst them and speaking to them about coming together on our station and several of them had not heard of the murder until I told them. (Gondongwe 2011, 245)

When the rebellion broke out in 1896, people arranged to kill Anta because they thought that it was because of him that the chiefs were killed in 1894. For Samkange (n.d.), Anta was against the actions of the police officers and he claims that, at one time, he had taken his gun to fight them. Until 1896, none of the people had forgotten about the events of 1894. While the various groups were plotting against the settlers, a number were plotting to kill James Anta. To quote one of the followers of Anta:

When the rebellion came people arranged to kill Anta because they said it was through him that the four men, their relatives, were killed. Those who arranged to do the killing were relatives of the dead Chief's (Zvimba's) wife. They gathered at night at the kraal of Matare the half-brother of the late Chief ... and they resolved to come at night and do the killing because they were afraid of ... one of the Chief's sons and Anta. They came where the congregation was singing beside the campfire. Anta knew people were coming, but thought that they were only visitors. They came up behind Anta and shot him in the neck ... Anta got up and ran away, shouting, "Someone is trying to kill me." He ran to the hut, but another man was waiting for him and killed him. It was in June 1896 that James Anta was murdered and was buried on some rocky outcrop some distance from the mission. (Matshobana n.d.)

One Wesleyan historian wrote in 1935 that “... when the full history of Mashonaland is written by some historian in the future, it may be found that James Anta was the first in the noble army of martyrs, who thus suffered for their faith. He had been a faithful witness to the power of the Gospel and his spirit never shrank ..." (Matshobana n.d.). Anta was killed because he was suspected of having been in complicity with the Europeans to kill the four chiefs in Lomagundi.

\section{MCZ's Unwillingness to Centre the Cornered History of James Anta}

Having discussed the brutal killing of Anta in the missionary field, one would expect MCZ to remember this sacrifice and give honour to Anta; yet this is not to be. There are a number of reasons that suggest that the Wesleyan Methodist Church has no deliberate 


\section{Mujinga}

intention to give credence to Anta. First, after the death of Anta, it took the Wesleyan Methodist Church 53 years to station a Rev. Matthew Rusike in the Hartleyton area of Lomagundi (Mujinga 2020, 7), suggesting that Anta's name was the talk of the village for over 53 years. It can be argued further that Anta evangelised Hartleyton area from the grave because after his assassination, there were no records of further killings of church workers. Thorpe justifies the negligence of the Hartleyton area as a mission field as caused by the shortage of European missionaries between 1897 until 1936 (Thorpe 1951).

The writer does not agree with Thorpe's assertion because the narrative of Shimmin mentioned earlier shows that Hartleyton mission was never meant for the missionaries but for the teacher-evangelists (Samkange n.d.). Shimmin worked very hard to establish the mission area and went further to name it after Marshal Hartley, who was the mission secretary in England. This action suggests that Hartleyton was not just a mission area for the local missionaries, but also that the Missionary Society in England had some interest in the area as well. It cannot be denied that the death of Anta reached England as sad news and was considered a blow to the missionary work in Hartleyton. In order to save themselves from the angry locals, the missionaries abandoned the mission areas. The narratives of Shimmin, as he was explaining their mission in Hartleyton, demonstrate that this was a central mission and abandoning it for 53 years was not wise. The missionaries revived the Hartleyton mission area by sending an African minister by the name of Rev. Matthew Rusike. In order to accept the station, Rusike was sent as a superintendent minister, which was the most prestigious position that any African minister could receive from the missionaries during those days (Mujinga 2020, 8). The missionaries made sure that the place was no longer hostile by leaving Rusike in the same area for 20 years, a practice that was only applied to Rusike (Mujinga 2020, 2).

The second point to argue the reluctance of Wesleyan Methodists to acknowledge the martyrdom of Anta, is the naming of a school in the Zvimba area (where Anta was killed) after Moleli, who was killed in Marondera more than 200km from the Zvimba area. There are two pieces of evidence that justify the lack of commitment by Wesleyan Methodists to honour James Anta as a Methodist martyr. The first evidence is the exposition of Gondongwe (2011), whose narrative seems to suggest how the Wesleyan Methodists usurped Anta's recognition and gave Moleli double recognition. Gondongwe mentioned:

In January 1898 Rev. John White reopened Nenguwo School [in Mashonaland East] establishing it near the shrine of Moleli as a way of fulfilling Moleli's dream. The first enrolment was of six young men. The idea was to give these candidates some training in biblical and theological knowledge to enable them to function as preachers and school masters. Rev. White wrote to Mr. Hartley on August 141899 and said: "If our work is to be a success we desire, we must have educated men" ... in 1915, Sir Joshua Waddilove donated the sum of $£ 1,500$ towards infrastructural development at Nengubo Institute. A grateful Wesleyan Methodist Church renamed the school Waddilove and this name survived to the present. (Gondongwe 2011, 3) 


\section{Mujinga}

An analysis of Gondongwe's statement shows that the renaming of Nengubo Training Institute as Waddilove Training Institute was not based on missional enterprise, since Moleli's grave is in the institution; but on economic grounds because Sir Waddilove had donated money to the institution. This point suggests that Wesleyan Methodist history is defined on political and economic grounds, and not on missional enterprise. For unknown reasons, Moleli, who sacrificed his life in the Nengubo area and was buried at Nengubo Institute, found his name dedicated in exactly the place where Anta was killed; thereby destroying Anta's name in the history of Wesleyan Methodism.

A follow-up to the last part of the above statement leads us to the third piece of evidence as to why the martyrdom of James Anta is forgotten history in the Wesleyan Methodism, which is the naming of Moleli High school after Modumedi Moleli. According to Wikipedia (n.d.,), Moleli High School is located in Mashonaland West Province, Makwiro, Chegutu district, Msengezi area near the town of Norton in the Zvimba area, 80 kilometres southwest of the Zimbabwean capital Harare. The school offers O' and A' levels in boarding facilities. The school was established in 1962 by Ronald E. Sellers of the Wesleyan Methodist Church in Zimbabwe and named after the late Methodist evangelist, Modumedi Moleli. According to the report of the Ministry of Primary and Secondary Education produced in 2018, Moleli High School was ranked number 11 on the list of the top 100 best schools, with a $92.3 \%$ pass rate at O' level, while Waddilove High School appeared at number 43, with $76.73 \%$ (Pindula 2018). The report by Gondongwe (2011) and the historical narrative of Wikipedia demonstrate the unwillingness of Wesleyan Methodists to do the "simple and logical" thing of giving the Anta name to a high school in Mashonaland West (where Anta was killed) and dedicating the school where the grave of Moleli lies in Mashonaland East, to Moleli.

Fourth, there is much talk about the work of teacher-evangelists in Zimbabwe just as narrative history, but without any hope of honouring them. In his message to the Wesleyan Methodist Church, upon attaining 100 years in propagating the gospel in Zimbabwe, the outgoing Bishop (Presiding Bishop) Rev. Farai Chirisa, thanked the selfless sacrifice made by simple but faithful servants who brought the gospel to Zimbabwe from South Africa; who included Anta. Chirisa mentioned:

... what God brought in our land through His simple but faithful servants is one of the exciting stories of this church ... the best tribute that we can pay to those who have gone before us is to give ourselves whole heartedly to continuing the work, setting forth the gospel in word, in deed and in our life together. (Chirisa 1991, 1)

Chirisa's statement was very general that the key people who died for their faith did not receive enough recognition.

In 2011, Wesleyan Methodists also celebrated 120 years of existence in Zimbabwe. Again, there was no deliberate move by any scholar, including the Presiding Bishop (formerly Bishop) Rev. Amos Ndhlumbi, to mention the role played by the evangelist, James Anta. Instead, Ndhlumbi confused history by mentioning that the first Methodist 


\section{Mujinga}

missionaries to Zimbabwe were Rev. Owen Watkins and Isaac Shimmin, who arrived at Fort Salisbury from the Methodist Missionary Society in Britain on 29 September 1891, accompanied by the teaching-evangelists from Southern Africa who were going to make evangelism easier by preaching to the fellow natives Africans (MCZ 2011, 1). Ndhlumbi further mentioned that the teacher-evangelists were important to spread the good news to fellow Africans and without them the missionaries' work would have been a complete failure (MCZ 2011, 1). In addition, the research by Samkange was meant for the Wesleyan Methodists to honour Anta; however, the church did not take any step after the research was done and this is a demonstration of the church's unwillingness to give honour where it belongs.

\section{Conclusion}

Although it is not clear why the Wesleyan Methodist Church took the decision of naming their schools the way they did, one can conclude that Anta was forgotten because he was young and unmarried. Since history is written by the victors, Wesleyan Methodists created a biased history by using African cultural epistemology, which has no place for people who die young and unmarried. This paper argues that, although Anta is an unsung hero, his martyrdom in the Wesleyan Methodist mission fields deserves ecclesiastical and scholarly recognition. This article is a reconstruction of Anta's life, given the fact that he was the youngest of the 10 evangelists and was not married, he sacrificed his life for the gospel as a missionary from South Africa; yet, until 2021, Wesleyan Methodists had not decided to celebrate his martyrdom. It is also evident from the Methodist properties that not any congregation, school or hall is named after James Anta; this deliberate forgetting of history creates a biased history. The paper concludes by challenging the Wesleyan Methodist Church to agree that Wesleyan Methodist historiography, without honouring Anta, is a void history that needs to be rewritten and reconstructed. This paper further challenges the Wesleyan Methodist Church to at least name a congregation in the name of James Anta as a way of correcting its biased history.

\section{References}

Banana, C. S. 1991. A Century of Methodism in Zimbabwe 1891-1991. Gweru: Mambo Press.

Chirisa, F. J. 1991. "A Message from the Retiring Bishop.” Centenary Celebrations. Harare: Methodist Church in Zimbabwe.

Graaf, B. 1988. Modumedi Moleli: A Teacher, Evangelists and Martyr to Mashonaland between 1892-1896. Gweru: Mambo Press.

Gondongwe, K. 2011. "African Ministers and the Emergence of Resistance to Colonial Domination: The Development of Indigenous Clergy in the Wesleyan Methodist Church in Zimbabwe from 1891 to 1980 ." PhD thesis, University of KwaZulu-Natal.

Hewson, L. A. 1951. An Introduction to South African Methodists. Cape Town: The Standard Press. 


\section{Mujinga}

Kumalo, S. R. 2009. Methodist with a History and a Black Future in South Africa: An Ecclesial and Socio-Political History of the Methodist Church of Southern Africa. Eikenhof: Africa Upper Room Ministries.

Madhiba, S. 2000. Struggles and Strides: A History of the Localisation Process of Methodism in Zimbabwe 1891-1996. Harare. Methodist Literature Department.

Makwehe, N. Z, Samkange, S. J. T., and Manyoba, C. 1986. "Report of a Visit to the Death Spot of the Pioneer and Martyr Evangelist James Anta." MCZ Archives. Unpublished Report presented to the Wesleyan Methodist Conference.

Matshobana, E. n.d. "James Anta: Missionary to Mashonaland, Martyr and Founder." Accessed May 21, 2021. Bulawayo History: https://www.bulawayo1872.com/history/anta_james.htm.

Mawire, L. 2015. Comnrades or at Variance? A Historical and Theological Analysis of the African Apostolic Church vis the Methodist Church in Zimbabwe. Harare: Connexional Bookshop.

Methodist Church in Zimbabwe (MCZ). 2011. Message from the Presiding Bishop. The Word, 1, 8. Harare: Connexional Bookshop.

Methodist Church in Zimbabwe (MCZ). 1986. Minutes of Conference. Harare. Methodist Church in Zimbabwe.

Millard, J. A. 1999. Samuel Mathabathe. Pretoria: UNISA Press.

Mujinga, M. 2017. The Historical Developoment of Methodism: A North-South Paradigm. Harare: Connexional Bookshop.

Mujinga, M. 2020. "A Reconstruction of Matthew Jacha Rusike's Contribution to the Rehumanisation of Dehumanised Children in Zimbabwe 1950-1978." Studia Historiae Ecclesiasticae 46 (3): 1-15. https://doi.org/10.25159/2412-4265/7970.

Pindula. 2018. Zimbabwe Top 100 O'Level Schools. Accessed May 20, 2021. https://www.pindula.co.zw/Zimbabwe_Top_100_O'_Level_Schools.

Samkange, S. J. T. n.d. "James Anta Martyr to Integrity.” Harare: Unpublished source available in the Wesleyan Methodist Church Archives.

Thorpe, C. 1951. Limpopo to Zambesi. London: The Cargate Press.

Wikipedia. n.d. Moleli High School. Accessed May 20, 2021. https://en.wikipedia.org/wiki/Moleli_High_School.

Zvobgo, C. J. 1991. The Wesleyan Methodist Missions in Zimbabwe 1891-1945. Gweru: Mambo Press. 